Supplement of Geosci. Model Dev., 14, 1037-1079, 2021

https://doi.org/10.5194/gmd-14-1037-2021-supplement

(C) Author(s) 2021. This work is distributed under

the Creative Commons Attribution 4.0 License.

(c) (1)

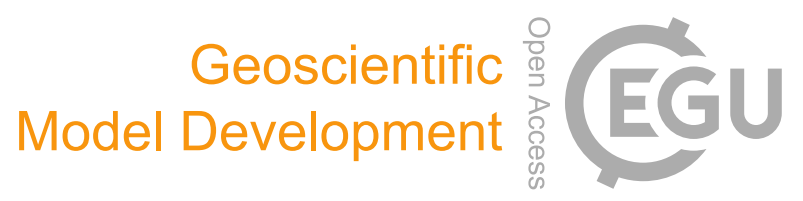

Supplement of

\title{
The global water resources and use model WaterGAP v2.2d: model description and evaluation
}

Hannes Müller Schmied et al.

Correspondence to: Hannes Müller Schmied (hannes.mueller.schmied@em.uni-frankfurt.de)

The copyright of individual parts of the supplement might differ from the CC BY 4.0 License. 


\section{Contents}

$\begin{array}{lr}\text { S1 Abbreviations } & 2\end{array}$

S2 Symbols used $\quad 3$

S3 WaterGAP application fields $\quad 6$

$\begin{array}{ll}\text { S4 Additional figures } & 7\end{array}$ 


\section{S1 Abbreviations}

\begin{tabular}{ll} 
AAI & area actually irrigated \\
AEI & area equipped for irrigation \\
CRU & Climatic Research Unit \\
CFA & areal correction factor \\
CFS & station correction factor \\
CS & calibration status \\
CSR & Center of Space Research \\
CU & consumptive water use \\
FAO & Food and Agriculture Organization of the United Nations \\
GHM & global hydrological model \\
GIA & glacial isostatic adjustment \\
GIM & Global Irrigation Model \\
GLWD & Global Lakes and Wetlands Database \\
GMIA & Global Map of Irrigation Area \\
GPS & Global Positioning System \\
GRACE & Gravity Recovery And Climate Experiment \\
GRanD & Global Reservoir and Dam database \\
GRDC & Global Runoff Data Centre \\
GSFC & Goddard Space Flight Center \\
GVA & gross value added \\
GWSWUSE & Groundwater-Surface Water Use \\
HID & Historical Irrigation Data set \\
ICU & irrigation consumptive water use \\
ISIMIP & Inter-Sectoral Impact Model Intercomparison Project \\
JPL & Jet Propulsion Laboratory \\
lg & global lakes \\
ll & local lakes \\
LResW & lakes, man-made reservoirs and wetlands \\
netCDF & network Common Data Form \\
res & global man-made reservoirs \\
TWSA & total water storage anomalies \\
WaterGAP & Water - Global Assessment and Prognosis \\
WGHM & WaterGAP Global Hydrology Model \\
wg & global wetlands \\
wl & local wetlands \\
WU & withdrawal water use \\
\hline
\end{tabular}




\section{S2 Symbols used}

Table S1: Symbols used for WaterGAP variables and parameters in the main paper. Note that there are many other model variables and parameters (e.g., downward shortwave and downward longwave radiation is also a model input).

\begin{tabular}{|c|c|c|c|}
\hline Symbol & description & unit & equations \\
\hline \multicolumn{4}{|c|}{ Model input: spatially distributed input variables } \\
\hline$P$ & precipitation & $m m d^{-1}$ & $2,3,22,24$ \\
\hline$T$ & daily air temperature & ${ }^{\circ} \mathrm{C}$ & $8,10,12,13$ \\
\hline \multicolumn{4}{|c|}{ Model input: spatially distributed input data (temporally constant) } \\
\hline$A_{\text {cont }}$ & continental area & $m^{2}$ & 35 \\
\hline$A_{\max }$ & maximum extent of the water body & $m^{2}$ & 23,26 \\
\hline$D_{r, b f}$ & river depth at bankfull conditions & $m$ & 33 \\
\hline$f_{d, l c}$ & fraction of deciduous plants & - & 5 \\
\hline$S_{r e s, \max }$ & storage capacity of reservoirs/regulated lakes & $m^{3}$ & 29 \\
\hline \multicolumn{4}{|c|}{$\begin{array}{l}\text { Spatially distributed model parameters derived from spatially } \\
\text { distributed input data (some derived using model parameters) }\end{array}$} \\
\hline$f_{g}$ & groundwater recharge factor & - & 19 \\
\hline$R_{g_{\max }}$ & $\begin{array}{l}\text { soil-texture specific maximum groundwater } \\
\text { recharge }\end{array}$ & $m m d^{-1}$ & 19 \\
\hline$s$ & river bed slope & $m m^{-1}$ & 32 \\
\hline$S_{c, \max }$ & maximum canopy storage & $m m$ & $3,4,6$ \\
\hline$S_{s, \max }$ & maximum soil water content & $m m$ & 17,18 \\
\hline$S_{l, \max }$ & maximum storage of the lake & $m^{3}$ & 24 \\
\hline$S_{r, \max }$ & maximum volume of the river & $m^{3}$ & 33 \\
\hline$S_{r e s, w, \max }$ & $\begin{array}{l}\text { maximum storage of the reservoir/regulated lake } \\
\text { and wetland }\end{array}$ & $m^{3}$ & 25 \\
\hline$l$ & river length & $m$ & $31,33,34$ \\
\hline$L_{\max }$ & maximum value of $L$ & - & 5 \\
\hline$L_{\min }$ & minimum value of $L$, & - & 5 \\
\hline$W_{r, b f}$ & river top width at bankfull conditions & $m$ & 33 \\
\hline \multicolumn{4}{|c|}{ Model output: storages } \\
\hline$S_{c}$ & canopy storage & $m m$ & $2,3,6$ \\
\hline$S_{g}$ & groundwater storage & $m^{3}$ & 20,21 \\
\hline$S_{l}$ & volume of water stored in the lake & $m^{3}$ & 24 \\
\hline$S_{l, r e s, w}$ & volume of water stored in the water body & $m^{3}$ & 22 \\
\hline$S_{l l, w l}$ & local lake or local wetland storage & $m^{3}$ & 27 \\
\hline$S_{l g, w g}$ & global lake or global wetland storage & $m^{3}$ & 28 \\
\hline$S_{r}$ & volume of water stored in the river & $m^{3}$ & $30,31,34$ \\
\hline$S_{\text {res }}$ & reservoir/regulated lake storage & $m^{3}$ & 29 \\
\hline$S_{r e s, w}$ & $\begin{array}{l}\text { volume of water stored in reservoir/regulated lake } \\
\text { or wetland }\end{array}$ & $m^{3}$ & 25 \\
\hline$S_{s}$ & soil water storage & $\mathrm{mm}$ & $15,17,18$ \\
\hline$S_{s n}$ & snow storage & $m m$ & $11,13,14$ \\
\hline \multicolumn{4}{|c|}{ Model output: flows } \\
\hline$E_{c}$ & evaporation from the canopy & $m m d^{-1}$ & $2,6,14,17$ \\
\hline
\end{tabular}




\begin{tabular}{|c|c|c|c|}
\hline$E_{s}$ & actual evapotranspiration from the soil & $m m d^{-1}$ & 15,17 \\
\hline$E_{s n}$ & sublimation & $m m d^{-1}$ & 11,14 \\
\hline$I C U$ & irrigation consumptive water use (crop specific) & $m m d^{-1}$ & 1 \\
\hline$M$ & snowmelt & $m m d^{-1}$ & $11,13,16$ \\
\hline$N A_{g}$ & net abstraction from groundwater & $m^{3} d^{-1}$ & 20 \\
\hline$P_{s n}$ & the part of $P_{t}$ that falls as snow & $m m d^{-1}$ & $11,12,16$ \\
\hline$Q_{g}$ & groundwater discharge & $m^{3} d^{-1}$ & 20,21 \\
\hline$Q_{r, \text { out }}$ & streamflow or river discharge & $m^{3} d^{-1}$ & $30,31,35$ \\
\hline$R$ & net radiation & $m m d^{-1}$ & 7 \\
\hline$R_{g}$ & diffuse groundwater recharge & $m m d^{-1}$ & 19,20 \\
\hline$R_{g_{l, r e s, w}}$ & $\begin{array}{l}\text { point groundwater recharge from surface water } \\
\text { bodies }\end{array}$ & $m^{3} d^{-1}$ & $20,22,26$ \\
\hline$R_{l}$ & runoff from land & $m m d^{-1}$ & $15,18,19$ \\
\hline$R_{n c}$ & net cell runoff & $m m d^{-1}$ & 35 \\
\hline \multicolumn{4}{|c|}{ Model parameters } \\
\hline$\alpha$ & Priestley-Taylor parameter & - & 7 \\
\hline$a$ & outflow exponent for local lakes and local wetlands & - & 27 \\
\hline$c_{e, l c}$ & $\begin{array}{l}\text { reduction factor for evergreen plants per land cover } \\
\text { type }\end{array}$ & - & 5 \\
\hline$D_{F}$ & land-cover specific degree-day factor & $m m d^{-1{ }^{\circ} C}$ & 13 \\
\hline$E_{p o t, \max }$ & maximum potential evapotranspiration & $m m d^{-1}$ & 17 \\
\hline$\gamma$ & runoff coefficient & - & 18 \\
\hline$g$ & psychrometric constant & $k P a^{\circ} C^{-1}$ & 7,9 \\
\hline$k$ & surface water outflow coefficient & $d^{-1}$ & 27,28 \\
\hline$k_{g}$ & $\begin{array}{l}\text { globally constant groundwater discharge coeffi- } \\
\text { cient }\end{array}$ & $d^{-1}$ & 21 \\
\hline$K_{g w_{l, r e s, w}}$ & groundwater recharge constant below LResW & $m d^{-1}$ & 26 \\
\hline$k_{\text {rele }}$ & reservoir release factor & - & 29 \\
\hline$l_{h}$ & latent heat & $M J k g^{-1}$ & 9,10 \\
\hline$m_{c}$ & canopy storage parameter & $m m$ & 4 \\
\hline$p$ & reduction exponent & - & 24,25 \\
\hline$p_{a}$ & atmospheric pressure of the standard atmosphere & $k P a$ & 9 \\
\hline$r$ & reduction factor for surface water bodies & - & $23,24,25,26$ \\
\hline$s_{a}$ & $\begin{array}{l}\text { slope of the saturation vapour pressure- } \\
\text { temperature relationship }\end{array}$ & $k P a^{\circ} C^{-1}$ & 7,8 \\
\hline$T_{f}$ & snow freeze temperature & ${ }^{\circ} \mathrm{C}$ & 12 \\
\hline$T_{m}$ & snow melt temperature & ${ }^{\circ} \mathrm{C}$ & 12 \\
\hline \multicolumn{4}{|c|}{ Internal variables } \\
\hline$A$ & global (or local) water body surface area & $m^{2}$ & 22,23 \\
\hline$D_{r}$ & river water depth & $m$ & 34 \\
\hline$E_{p o t}$ & potential evapotranspiration & $m m d^{-1}$ & $6,7,14,17,22$ \\
\hline$E_{p_{o t}}$ & crop-specific optimal evapotranspiration & $m m d^{-1}$ & 1 \\
\hline$L$ & one-side leaf area index & - & 5 \\
\hline$n$ & river bed roughness & - & 32 \\
\hline$N A_{l, \text { res }}$ & net abstraction from the lakes and reservoirs & $m^{3} d^{-1}$ & 22 \\
\hline$N A_{s, r}$ & net abstraction of surface water from the river & $m^{3} d^{-1}$ & 30 \\
\hline$P_{e f f}$ & effective precipitation & $m m d^{-1}$ & $15,16,18$ \\
\hline
\end{tabular}




\begin{tabular}{llll}
$P_{\text {irri,eff }}$ & effective precipitation for irrigation & $m m d^{-1}$ & 1 \\
$P_{t}$ & throughfall (fraction of $P$ that reaches the soil) & $m m d^{-1}$ & $2,3,12,16$ \\
$Q_{\text {in }}$ & inflow into water body from upstream & $m^{3} d^{-1}$ & 22 \\
$Q_{\text {out }}$ & outflow from the water body to other surface water & $m^{3} d^{-1}$ & $22,27,28$ \\
& bodies including river storage & & \\
$Q_{r, \text { in }}$ & inflow into the river compartment & $m^{3} d^{-1}$ & 30,35 \\
$R_{h}$ & hydraulic radius of the river channel & $m$ & 32 \\
$v$ & river flow velocity & $m d^{-1}$ & 31,32 \\
$W_{r, \text { bottom }}$ & river bottom width & $m$ & 33,34 \\
\hline
\end{tabular}




\section{S3 WaterGAP application fields}

WaterGAP has been used in a broad field of applications. To evaluate recent usage of WaterGAP model output for research, we assessed the publications that cite the paper describing WaterGAP2.2, Müller Schmied et al. (2014), hereafter referred to as MS2014. In https://webofknowledge.com, 130 citations were found until 08.04.2020. Of course, other WaterGAP studies (as e.g. Alcamo et al. (1998); Döll et al. (2003); Müller Schmied et al. (2016); Döll et al. (2014)) were also cited numerous times since the publication of MS2014, but we assume that the assessment based on the citations of this paper can provide a representative overview of WaterGAP usage.

Topic-wise, MS2014 was cited in the scope of climate change impact assessments (18), Life Cycle Analyses (14), TWSA applications, mostly in combination with GRACE (12), model evaluation (11), model development and calibration (10), groundwater stress, depletion and storage change (8), (model) reviews (8), data assimilation (7), water scarcity/stress (7) and water use (5). Other application fields with more than one citation are sea-level rise, waterenergy-food nexus, economy, geodesy methodology, drought, ecology / environmental flows, floods, commentary / editorials and root zone-specific data sets. These usages fit well into the motivation of WaterGAP development as highlighted in Alcamo et al. (1998) and Döll et al. (2003), especially as water use and water availability are studied in both historical and future scenario perspectives.

The spatial coverage of the citing literature has been global in most cases (66), followed by multiple basins (19), single (large) basins (17), single countries (14) and single continents (9). The high amount of global-scale usage indicates the demand of spatially consistent and ubiquitously available model output for assessment purposes and model evaluation. The relatively high subglobal-scale usage indicates that, for many regions of the globe, the global WaterGAP model is considered to be a very important source of data.

While 35 out of 130 citing publications only used methods and assessments of MS2014, the others directly used WaterGAP output data. Usage of water storage output (either total or single/multiple components) was dominant (35), followed by streamflow and runoff (31), and water use (25). In particular, the GRACE satellite mission boosted the evaluation of WaterGAP water storage estimates and allowed for novel ways of data integration and model output evaluation. The high share of studies incorporating streamflow and runoff indicates the importance of these variables as they are the basis for multiple climate change impact assessment and evaluation studies. Most likely, the basin-specific calibration, which results in a relatively high model performance as compared to other GHMs, increases the value of runoff and streamflow output. Within the Life Cycle Assessment community, water use and availability estimates of WaterGAP have been used frequently. In five studies, groundwater-related output and, in four cases, multiple model outputs were applied. Single studies analyzed WaterGAP evapotranspiration and radiation.

Even though MS2014 describes the WaterGAP 2.2 model (with a $0.5^{\circ} \times 0.5^{\circ}$ spatial resolution), seven studies refer to this paper even though WaterGAP 3 model output (with 5

$' \times 5^{\prime}$ spatial resolution) was studied. The hydrological process representations are similar in both model version families, however the technical settings are different. 21 studies refer to MS2014 in relation to ISIMIP (www.isimip.org), which highlights the contribution of WaterGAP to this societally and scientifically relevant initiative. 


\section{S4 Additional figures}

This section consists of additional figures, which might help to understand specific contents of the main text.

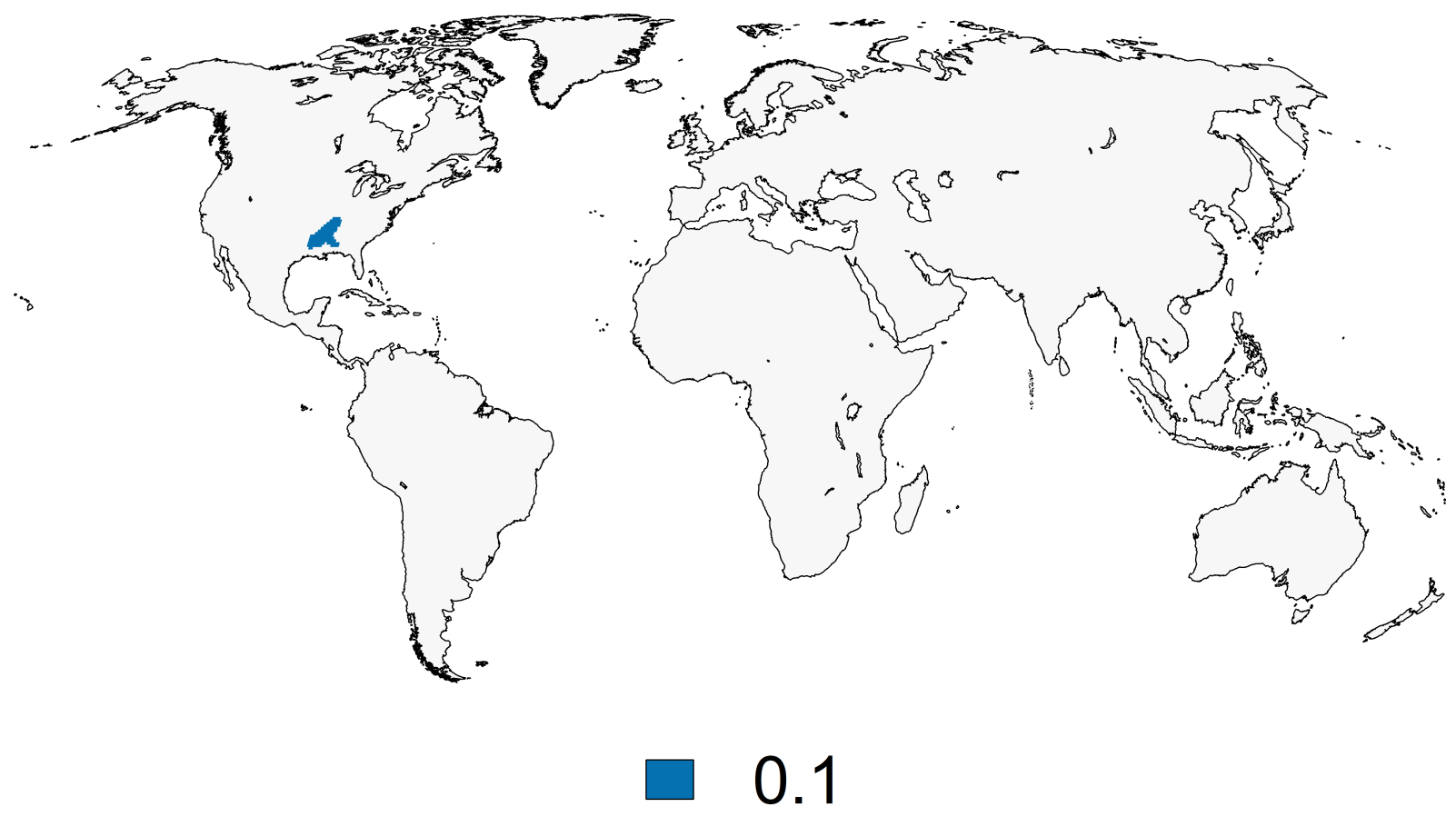

Figure S1: Regional correction of the groundwater factor $f_{g}$ to allow more realistic groundwater recharge rates. 

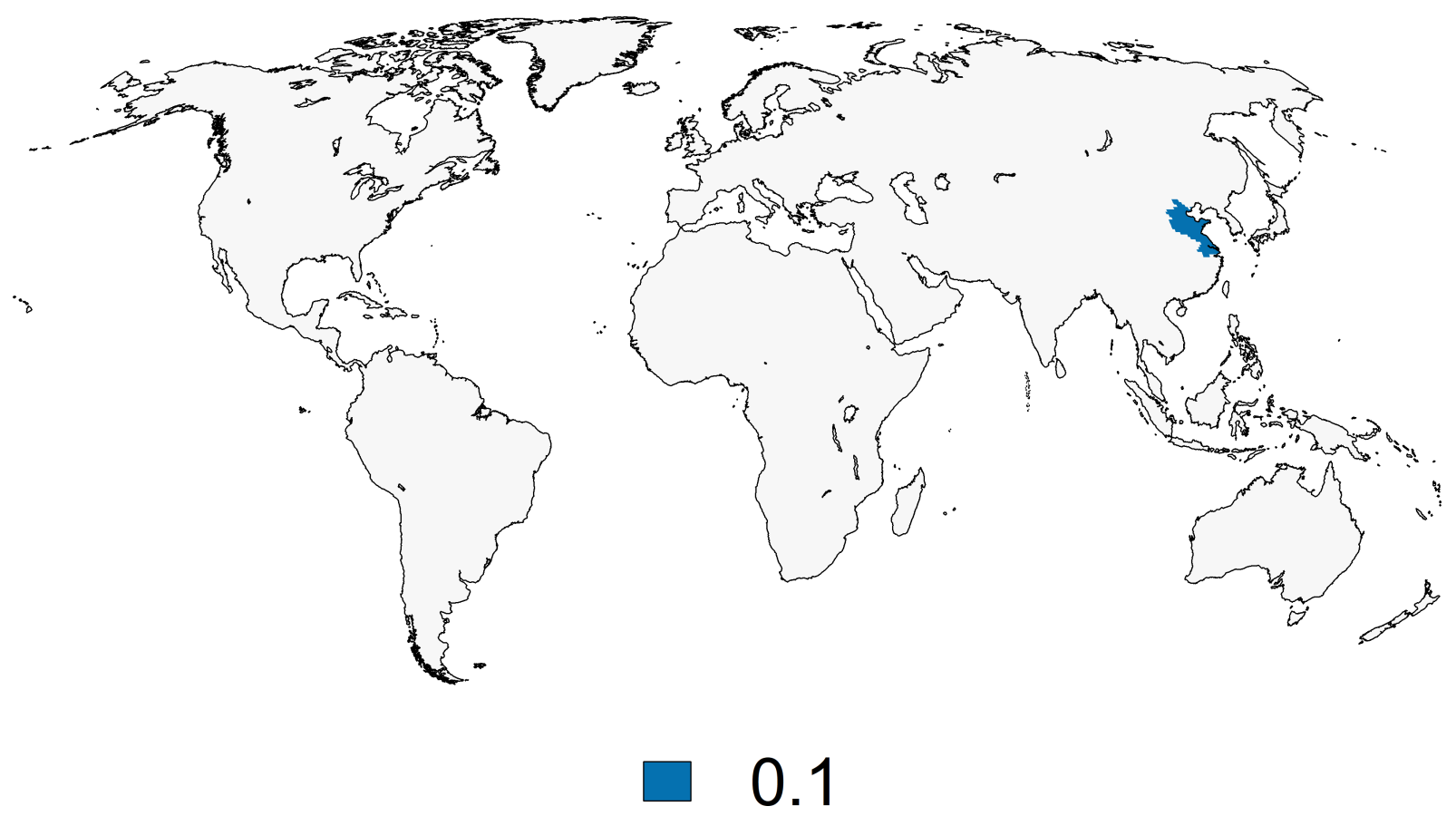

Figure S2: Regional correction of calibration parameter $\gamma$ to allow more realistic groundwater recharge rates.

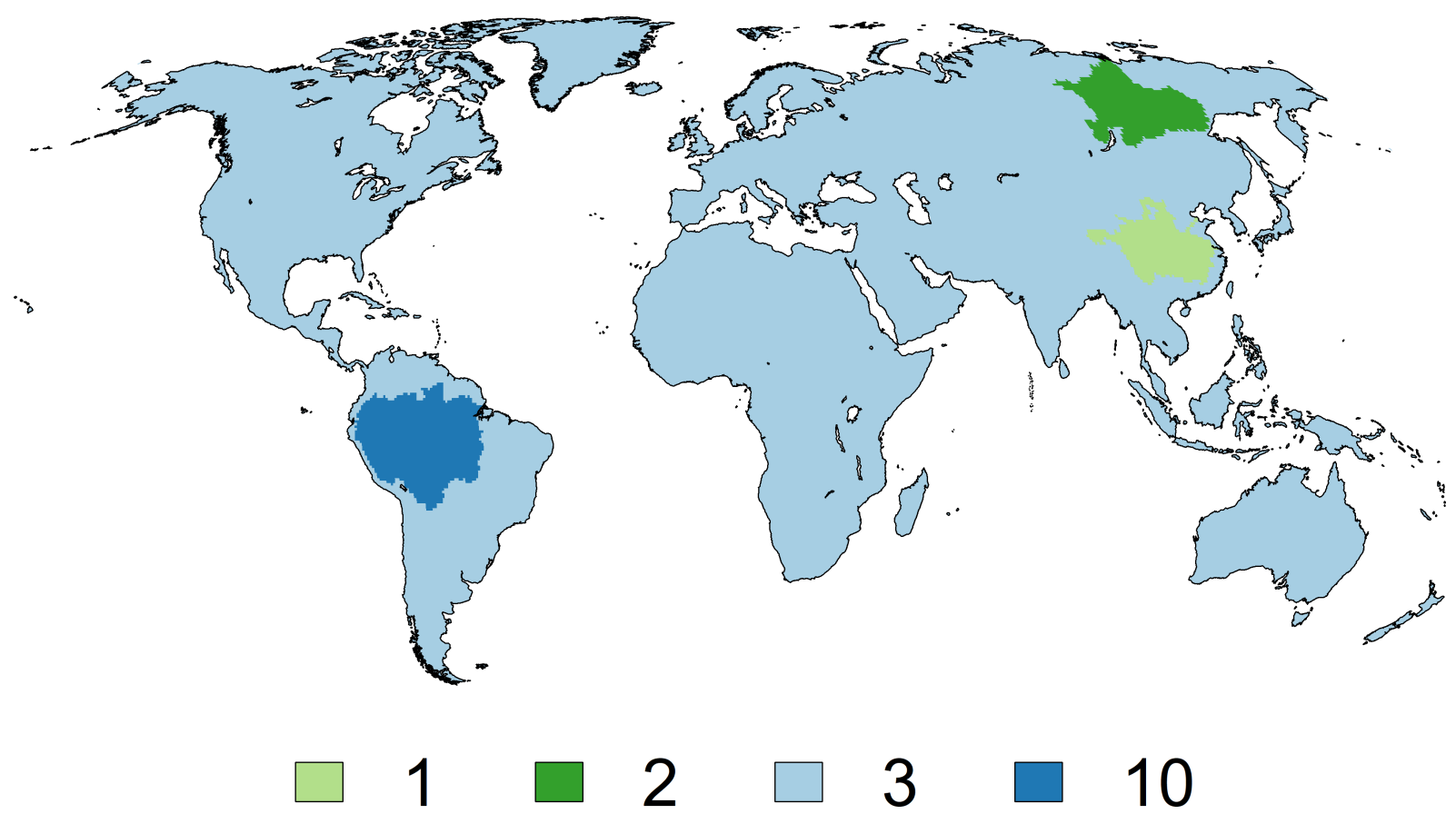

Figure S3: Region-specific multiplier for river roughness. 

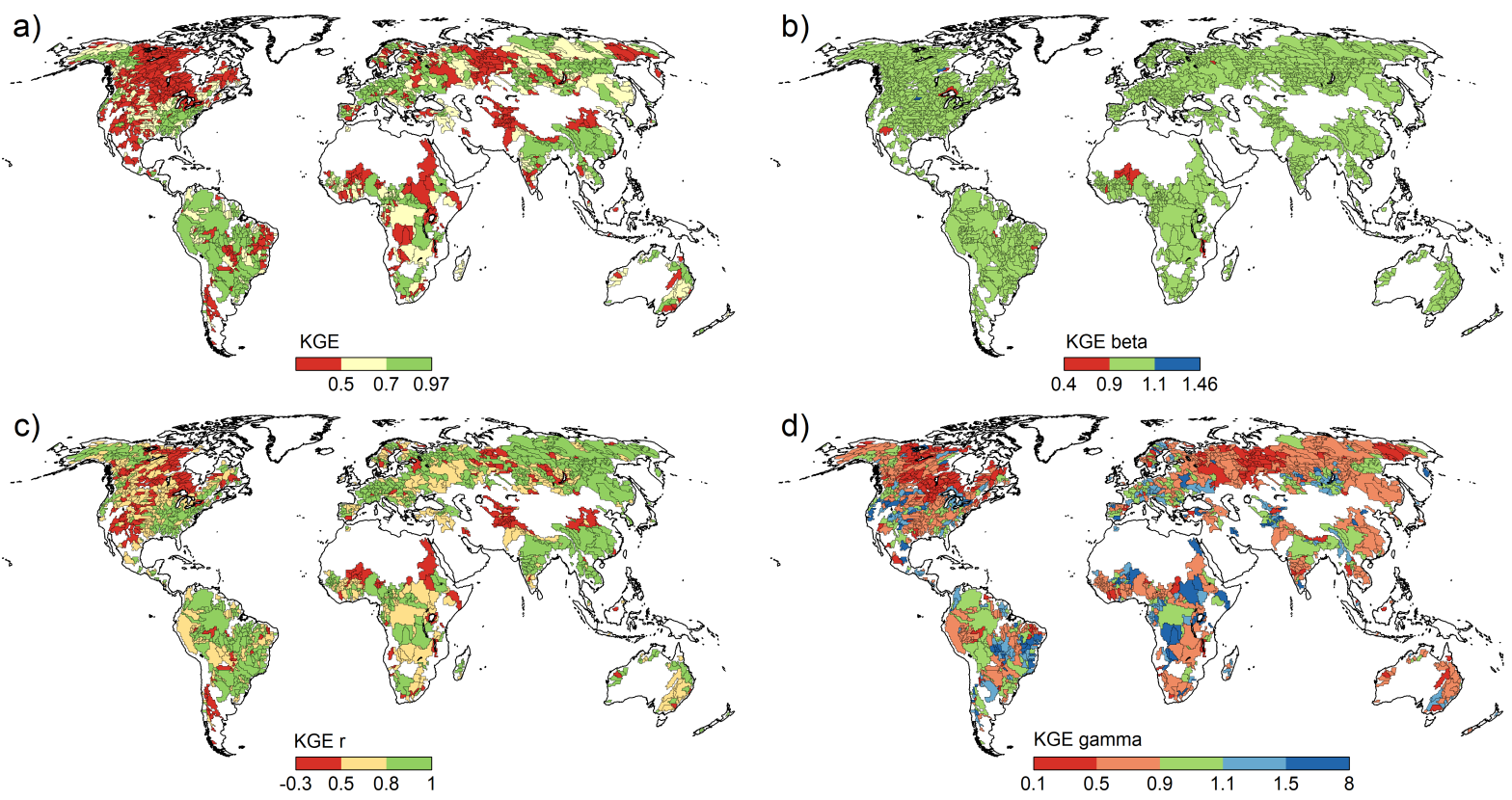

Figure S4: KGE and its components range at 1319 river basins for WaterGAP 2.2
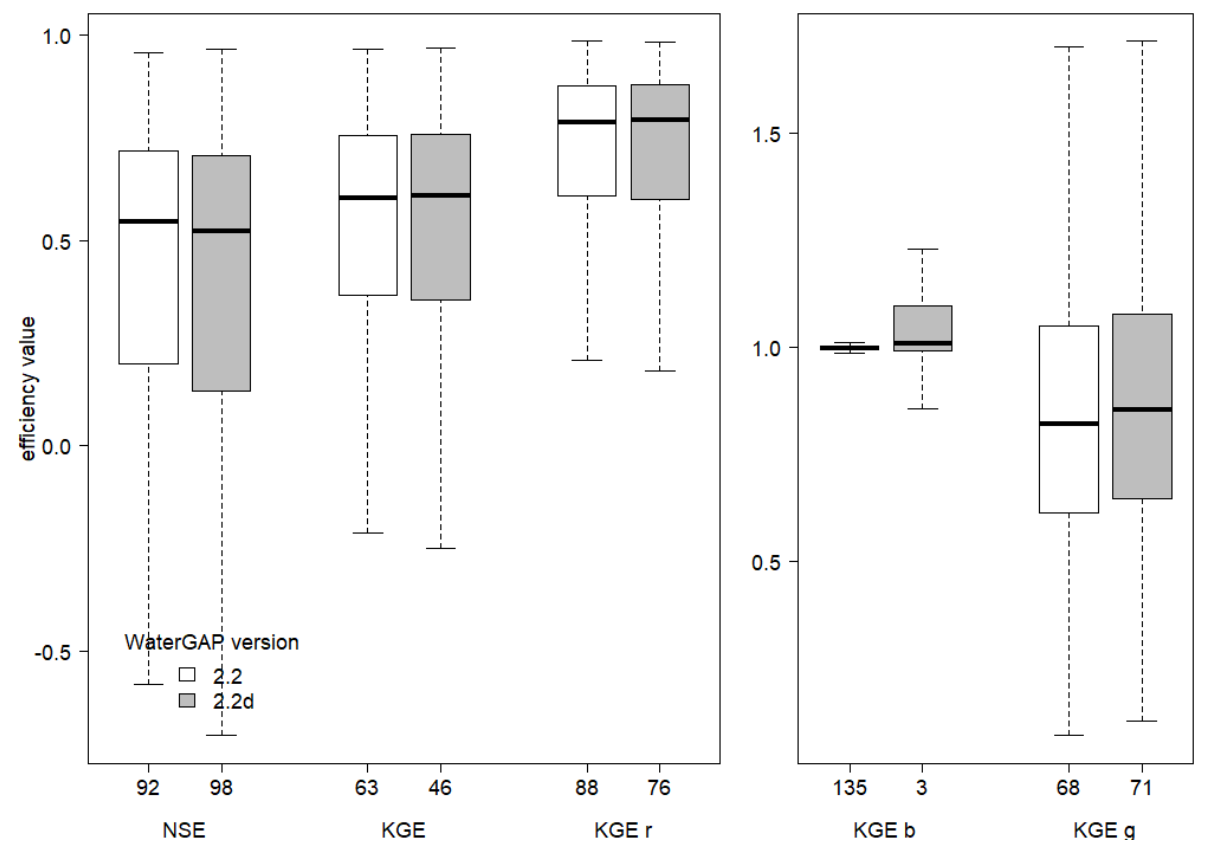

Figure S5: Efficiency of streamflow for the 1319 river basins in comparison of model versions WaterGAP 2.2d and WaterGAP 2.2 showing similar model performance. Outliers are excluded but number of outliers indicated at $\mathrm{x}$ axis. 

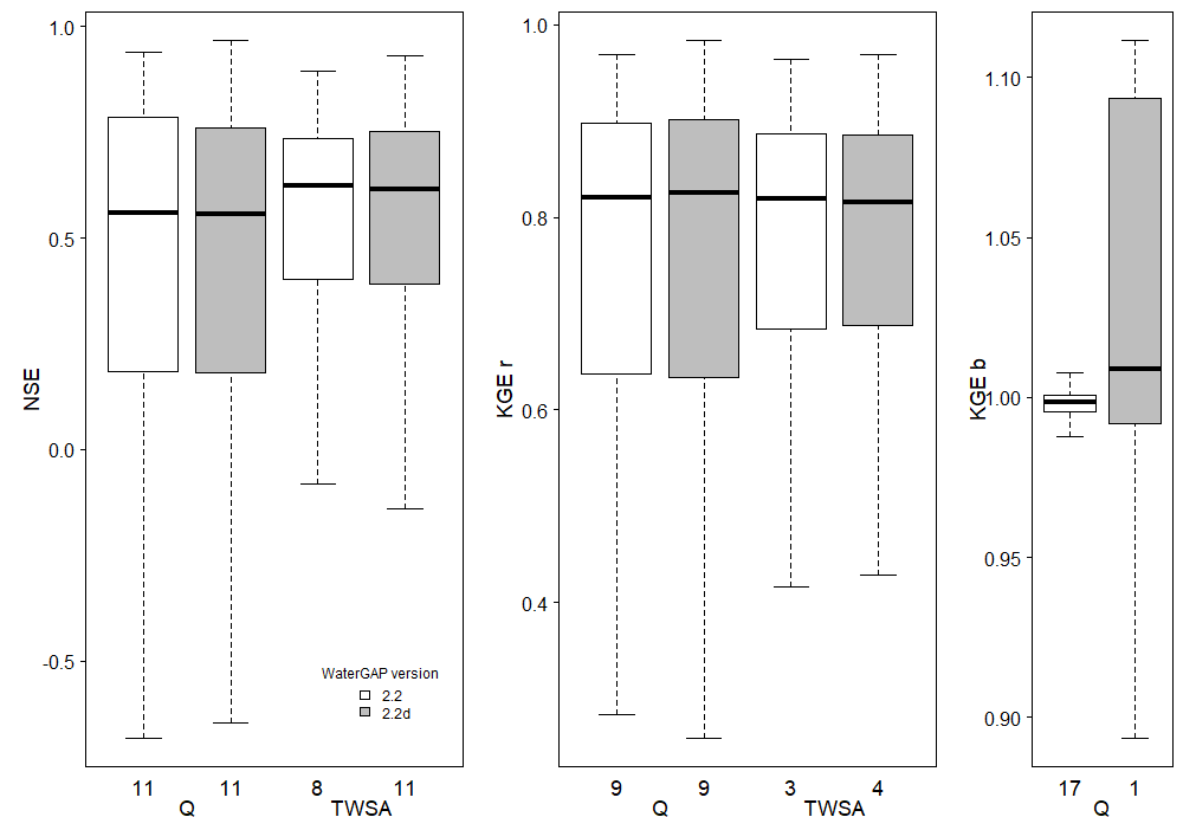

Figure S6: Efficiency of streamflow and TWSA for the river basins larger than 200,000 $\mathrm{km}^{2}$ in comparison of model versions WaterGAP 2.2d and WaterGAP 2.2 showing similar model performance. Outliers are excluded but number of outliers indicated at $\mathrm{x}$ axis.

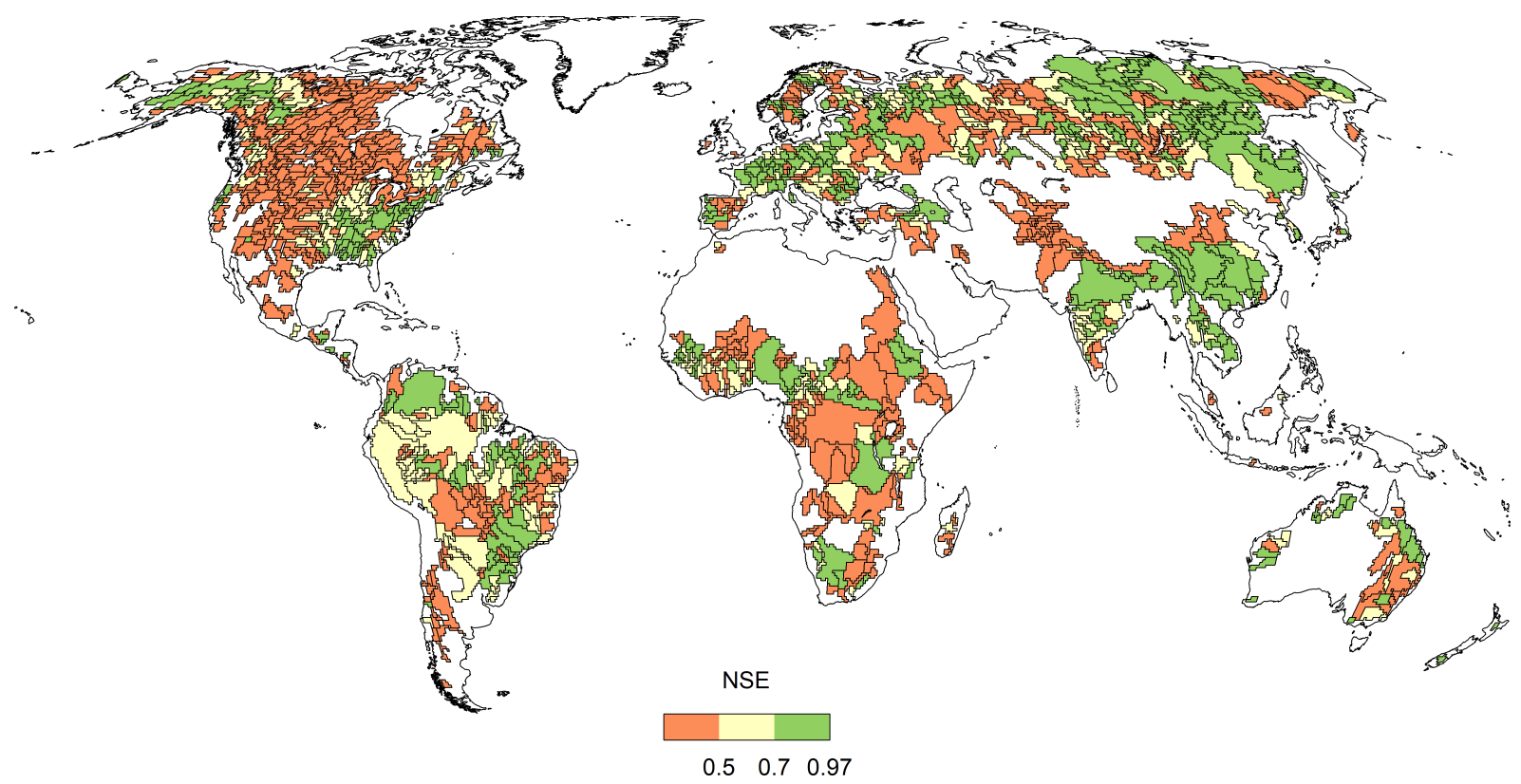

Figure S7: Classified NSE efficiency metric represented for the 1319 river basins and WaterGAP 2.2 . 


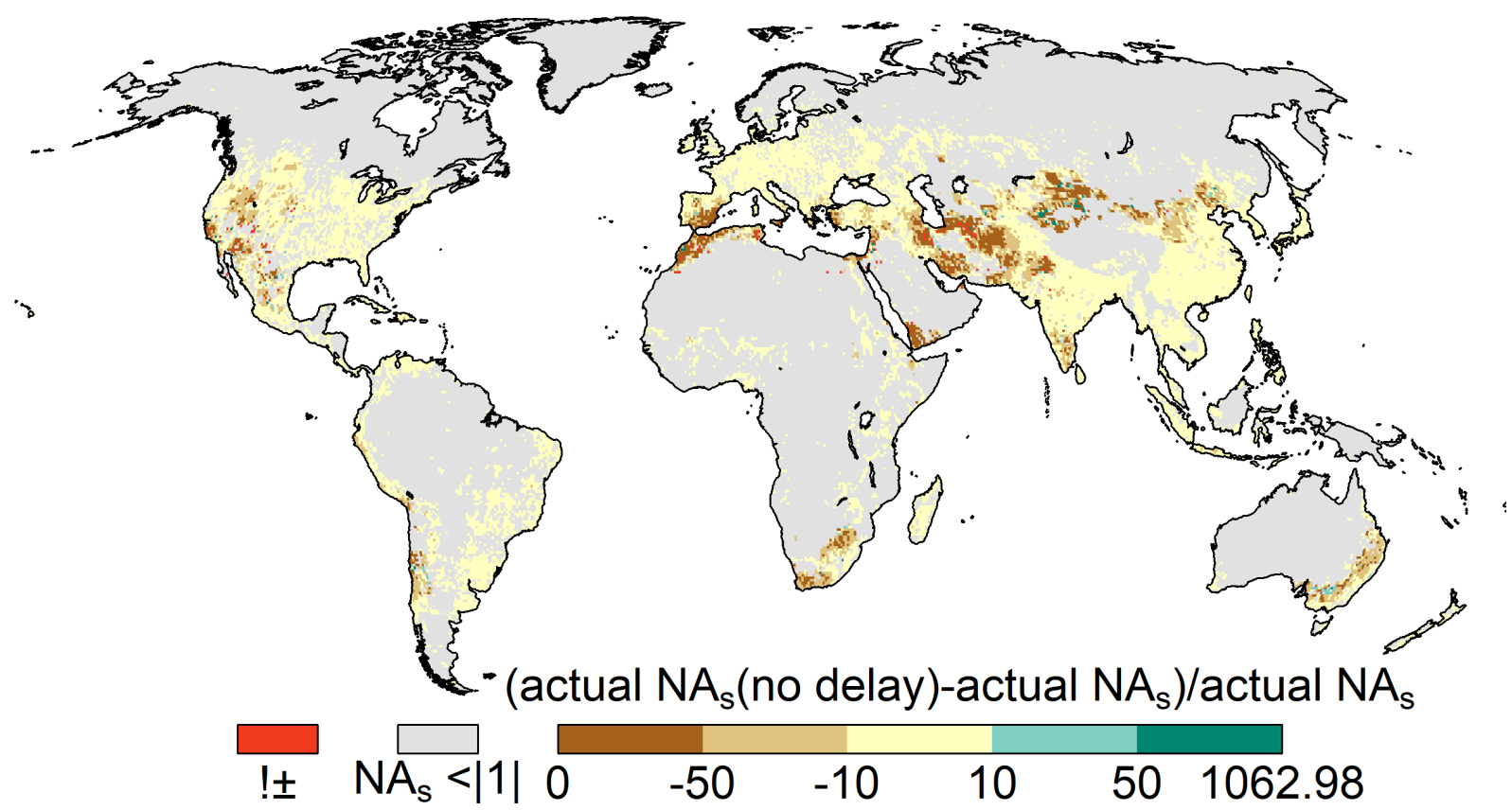

Figure S8: The spatial impact of delayed satisfaction of $N A_{s}$, showing a lower satisfaction especially in dry regions compared to the standard variant. Values are expressed in percent.

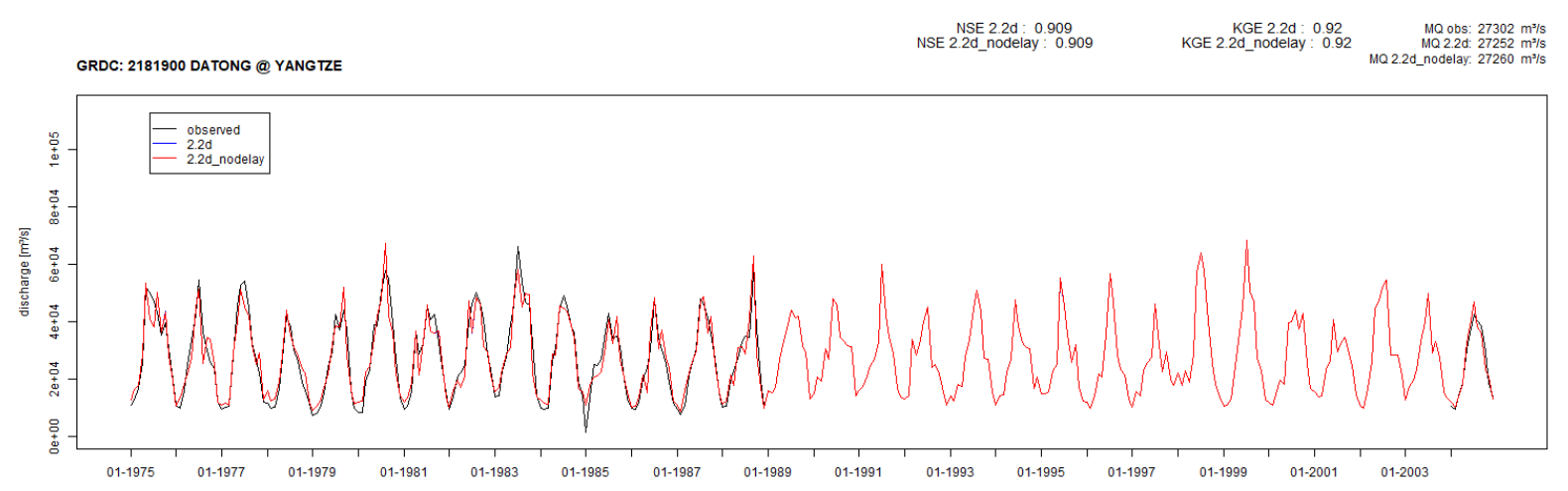

Figure S9: Hydrograph of Yangtze river at Datong station with standard 2.2d and a variant without delayed satisfaction of water use as well as with the GRDC data included.

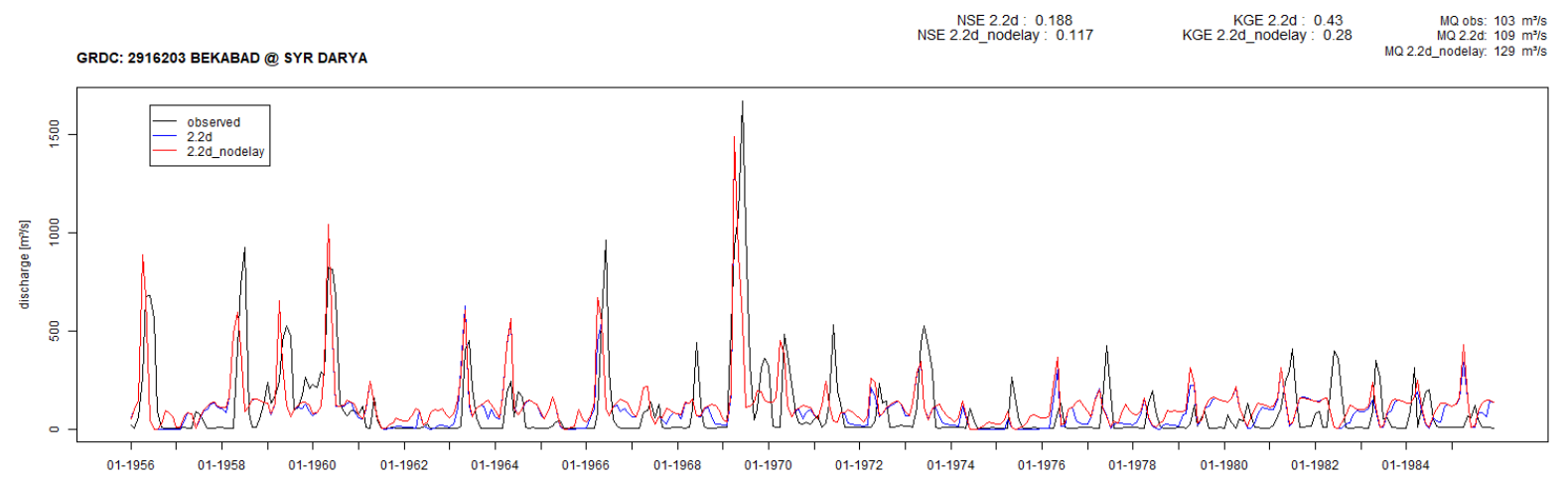

Figure S10: Hydrograph of Syr Darya river at Bekabad station with standard 2.2d and a variant without delayed satisfaction of water use as well as with the GRDC data included. 


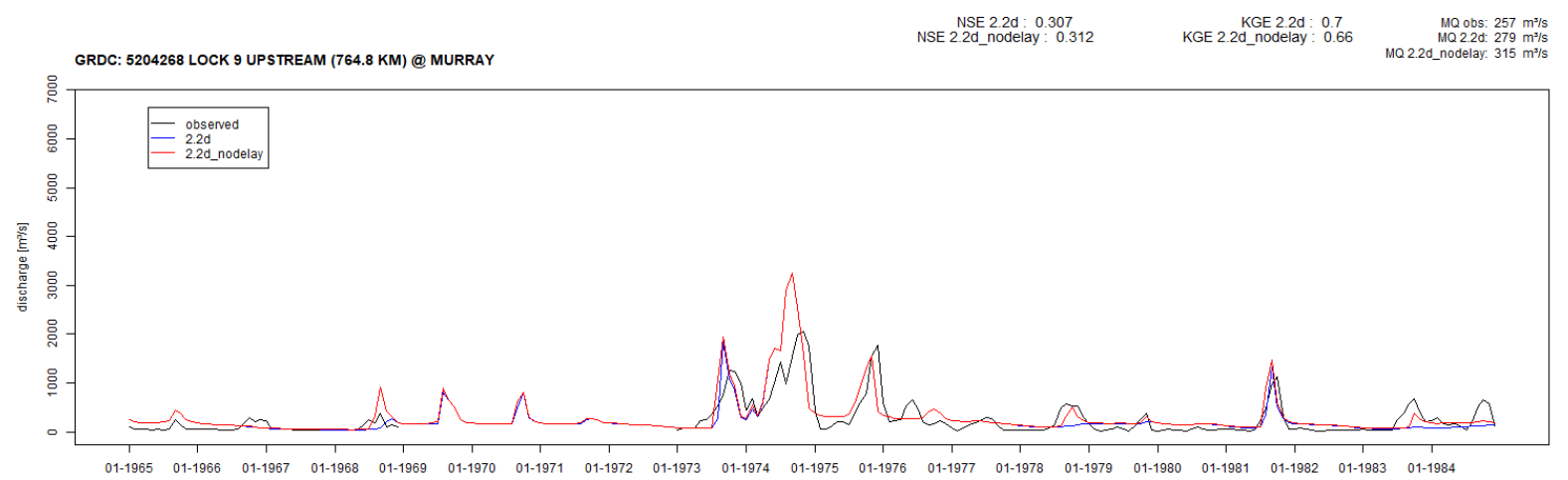

Figure S11: Hydrograph of Murray river at Lock 9 station with standard 2.2d and a variant without delayed satisfaction of water use as well as with the GRDC data included.
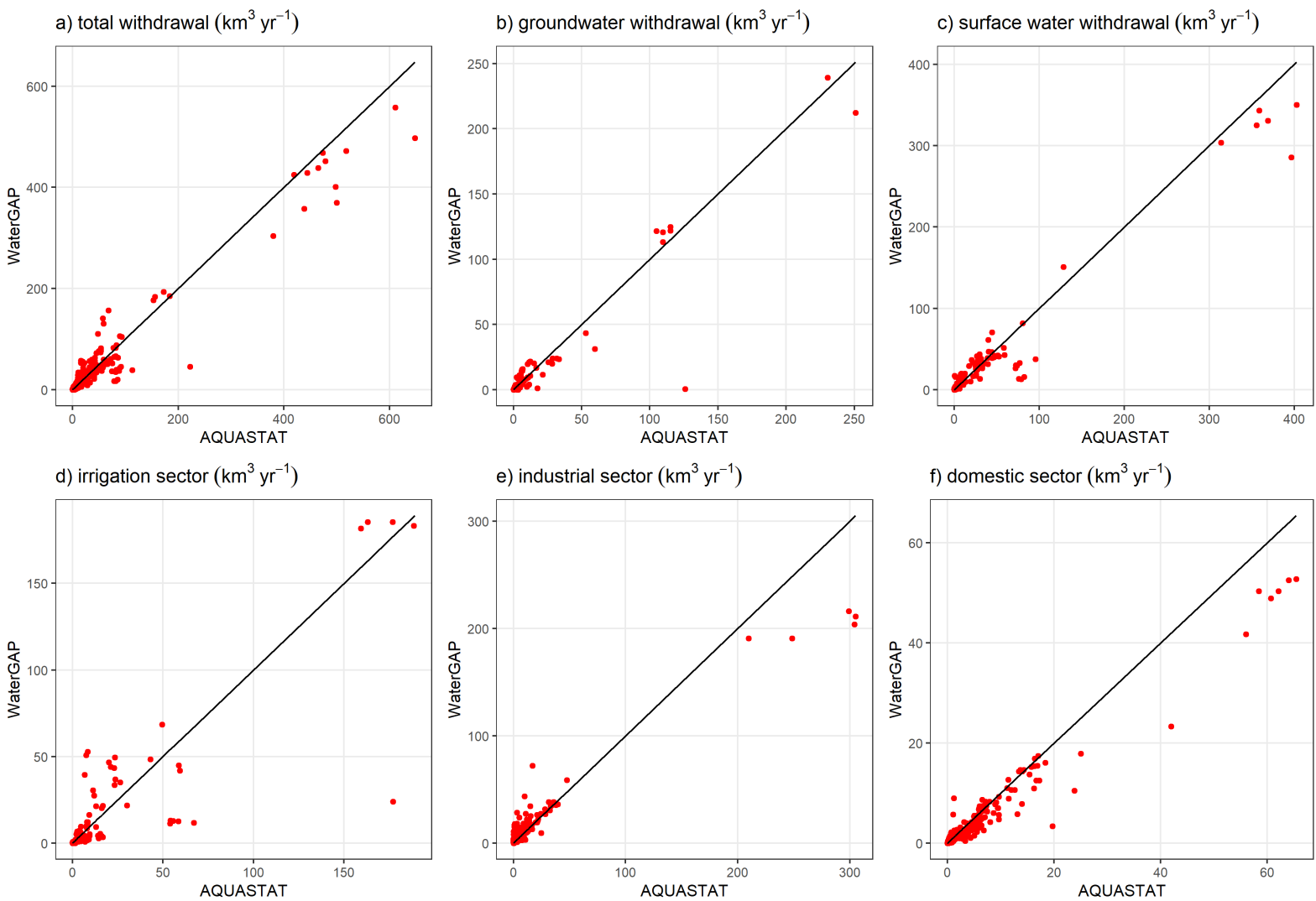

Figure S12: Comparison of potential withdrawal water uses from WaterGAP 2.2d with AQUASTAT (FAO, 2019). Each data point represents one yearly value (if present in the database) per country for the time span 1962-2016. Same as Fig. 5 from the main paper but not with logarithmic axes. 


\section{References}

Alcamo, J., Leemans, R., and Kreileman, E.: Global Change Scenarios of the 21st Century - Results from the IMAGE 2.1 Model, Pergamon, Oxford, 1998.

Döll, P., Kaspar, F., and Lehner, B.: A global hydrological model for deriving water availability indicators: model tuning and validation, Journal of Hydrology, 270, 105-134, https://doi.org/10.1016/S0022-1694(02)00283-4, 2003.

Döll, P., Müller Schmied, H., Schuh, C., Portmann, F. T., and Eicker, A.: Global-scale assessment of groundwater depletion and related groundwater abstractions: Combining hydrological modeling with information from well observations and GRACE satellites, Water Resources Research, 50, 5698-5720, https://doi.org/10.1002/2014WR015595, 2014.

FAO: AQUASTAT, URL http://www.fao.org/aquastat/en/, 2019.

Müller Schmied, H., Eisner, S., Franz, D., Wattenbach, M., Portmann, F. T., Flörke, M., and Döll, P.: Sensitivity of simulated global-scale freshwater fluxes and storages to input data, hydrological model structure, human water use and calibration, Hydrology and Earth System Sciences, 18, 3511-3538, https://doi.org/10.5194/hess-18-3511-2014, 2014.

Müller Schmied, H., Adam, L., Eisner, S., Fink, G., Flörke, M., Kim, H., Oki, T., Portmann, F. T., Reinecke, R., Riedel, C., Song, Q., Zhang, J., and Döll, P.: Variations of global and continental water balance components as impacted by climate forcing uncertainty and human water use, Hydrology and Earth System Sciences, 20, 2877-2898, https://doi.org/ 10.5194/hess-20-2877-2016, 2016. 